UDC 81'33: 811.134.3

https://doi.org/10.31548/philolog2021.02.084

\title{
PORTUGUESE FOR AUDIT AND ACCOUNTING: VARIABILITY IN THE MONOMIAL STRUCTURE
}

\author{
O. I. CHAIKA, PhD in Philology, Associate Professor, \\ National University of Life and Environmental Sciences of Ukraine \\ E-mail: oxana.chaika@yahoo.es \\ https://orcid.org/0000-0002-4317-9456
}

\begin{abstract}
The paper considers Portuguese for Audit and Accounting as a specific domain of knowledge and studies the terminological expressions, or terminological collocations, subject to Chernovaty's classification of terms, or according to Chaika (2019, 2020), linguistic monomials as set term clusters in relevant terminologies, or languages for specific purposes (LSP). In order to demonstrate the application of methodology, this time it is Portuguese for Audit and Accounting, which serves to meet the objectives of the current study. The paper aims to reveal certain approaches to analyse the structure of the monomial in linguistics. Such approaches vary from the structural analysis of the set term cluster (monomial) by the number of components / elements in the structure, morphological class of the head term in the monomial structure, to their role in a sentence under a professional setting, as well as syntactic patterns as basic units of syntax, which are logically, grammatically, and semantically arranged. The result is unique inseparable conceptual (semantic) value of such monomials in Portuguese for Audit and Accounting. The list of approaches to study and analysis of the designated field and the respective material is not exhaustive. The examples of monomials in Portuguese for Audit and Accounting are selected from the Glossary of Terms, the Handbook of International Quality Control, Auditing, Review, Other Assurance, and Related Services Pronouncements validated by the International Auditing and Assurance Standards Board (IAASB). It is revealed that distinct similarities identified in the course of work with Portuguese for Audit and Accounting may take to relevant classifications attributable with the same set of criteria for the Ukrainian, English, German, Spanish languages as representatives of the Slavic, Germanic, and Romance families. The further prospect lies in performing comparative and contrastive analyses of the mentioned language material in respective LSP corpora.
\end{abstract} Accounting.

Key words: Monomial, terminology, language for specific purposes (LSP), Portuguese for Audit and

Introduction and literature review. Nomination, or naming, as a linguistic phenomenon makes an inseparable part of the human activities in the cognitive context of data perception, processing, identification of properties, labelling, image / concept retrieval, etc. Historically, naming first covered the objects and actions associated with everyday life and surroundings, natural phenomena such as wind, frost, draught, flood and so on. Further, with the evolutionary pace, it moved to natural sciences and arts - biology, medicine, zoology, mathematics, inter alia. With the advance of industrial era, creation of terms became inevitable in order to communicate distinct and accurate ideas in professional contexts. Since the birthmoment of term, there have been various attempts to address the issues of terminology unification. Standardization of terms has always been significant and needed across the geographies and languages. Reading L'Homme (2015), it is necessary to mention the linguistic consequences that link to the principles applied to produce clear and accurate naming conventions. Among these, such are: 1) "terms are viewed as canonical labels isolated from the text", 2) "terms are assumed to be linguistic labels that can be superimposed on knowledge configurations", 3) "most terms are nouns", 4) "designations tend to be complex" [11]. In addition, Khan (2016) speaks about the nature of reference, which distinguishes the term from the word. Next, the researcher focuses on the term as mono-referential in a very specific concept in a very specific area, which is characterized by a number of restrictions, e.g. lexical, syntactical and semantic, as well as generic, portative, and casual [12, p. 697]. Moving with the definitions of the term by Wüster, Rondeau and Sager $[20 ; 15$; 16], to those by Hoffmann, Herbert, Godman \& Payne in Pearson (1998) [14, p.18], in most cases terms are assumed to be labels, which are expressed by the noun. It is not argued that nouns label terms in their majority and as compared to monomials, Chaika (2021) also discusses the nounal monomial patterns in audit and accounting [9].

With identification, analysis and discussion of linguistic monomials in Portuguese for Audit and Accounting $(A \& A)$, it is important to emphasize that the focus shifts to term candidates, or monomials. These are set term clusters in a relevant terminology, or LSP, largely speaking, which rigid form of coinage and usage presupposes another treatment according to their lexical, semantic, and syntactic roles $[5 ; 6 ; 7 ; 8]$. Such monomials in Portuguese for A\&A may include a set number of irreversible elements (terms) in their structure and be expressed by the morphological class of the head term other than the noun. Moreover, the said set term clusters may include terms of specific domain of 
knowledge and some common use words. Such arrangement of elements (terms) in the term cluster has not been fixed as a term candidate in glossaries and dictionaries yet. However, the role for concordances becomes critically high. The point is such monomials as analysed in Chaika (2020) regularly appear unchanged in their form under a professional setting, which may lead to conclusion that they are more than a single term, i.e. a term expressed by one element only (and a noun) in a terminology, or LSP $[6 ; 7 ; 8]$. Thus, the relevance of the present work lies in following Hoffmann's three important aspects of the terminologies of LSPs as described in AlberDewolf (1980) [1, p.31]:

(i) The terminology of a[n] LSP is part of a vocabulary of specific areas of human activity,

(ii) The terminology of a[n] LSP forms within the language corpora of a particular layer,

(iii) The terminology of $a[n]$ LSP is more easily managed by field experts and makes part of a conscious process connected with language creation, including neologisms in terminology and professional jargon.

Given the above, Portuguese monomials in the field of audit and accounting are set term clusters attributive to specific areas of human activity, found within the language corpora of a particular layer, easily managed by accountants, auditors, financial analysts, economists and relevant field experts. Ultimately, Portuguese A\&A monomials are in the permanent process of live development in language and speech. It is arrived in Chaika (2021) that their origin other than nounal may hardly restrict creation, or coinage of more monomials, which may be lengthy enough and expressed by different parts of speech as required by the head term in the monomial structure.

Study material and methods. The terminological bank of monomials in Portuguese for A\&A furnishes the paper with the examples, which help provide some insights into feasibility and introduction of some classification for A\&A monomials in the Portuguese language. Such monomials are selected from Glossary of terms in the Handbook of International Quality Control, Auditing, Review, Other Assurance, and Related Services Pronouncements (Volume I), validated by the International Auditing and Assurance Standards Board (IAASB). The methods applied are use of the English language corpora in the LSP field of audit and accounting, internet resources, linguistic field research, etc. Data identification (yet manually), collection and processing are combined with the grammar-oriented component analysis and distributive method. Description is one of the main methods applied.

Discussion and results. Given the aim of the research, the set objectives deem to verify the hypotheses of variability in the monomial structure under Portuguese for A\&A. It is noteworthy that the current research may integrate certain ideas due to a number of previously carried out researches in Chaika (2019), Chaika (2020) and Chaika (2021). The mentioned studies also analysed the structure of the A\&A monomials in the English and Ukrainian languages.

Thus, by combing through the available findings of the linguistic data, it is supposed that some similarities in the monomial coinage, conceptual framework and functional use are very distinct in the Slavic and Germanic languages, Ukrainian, Russian, English, in particular. Altogether, there are some classifications, which may exemplify a wide range of monomials in Portuguese for A\&A according to a certain bank of criteria.

(A) Classification of monomials in Portuguese for A\&A according to the structural analysis,

(B) Classification of monomials in Portuguese for $A \& A$ according to the morphological class of the head term in the monomial structure,

(C) Classification of monomials in Portuguese for A\&A according to a syntactical role in a sentence under a professional setting.

Classification A considers and analyses the monomial by the number of components / elements in the structure. Following the previous results of the studies, monomials in Portuguese for $A \& A$ are differentiated as the below:

- Simple monomials, which are beyond the scope and aim of the research. Such bring very little interest here as simple monomials may be confused with the traditionally used in linguistics terms. Similarly, some terms and simple monomials are represented by a single element and are not a set expression, collocation, or cliché in a terminology. It is admitted that under a circumstance a term as placed in another non-professional setting may acquire properties of a common use word or vice versa. For example, please see the following: PT não resposta EN non-response 'a failure of the confirming party to respond, or fully respond, to a positive confirmation request, or a confirmation request returned undelivered' [IAASB: 32].

- Simplified monomials, which are set term clusters that consist of two terms (elements) only and often referred to as bi-terms, e.g. in Chaika (2020) [5; 6]. For instance, these are as below: PT opinião de auditoría 'audit opinion' [IAASB: 33], PT documentação de auditoría 'audit documentation' [IAASB: 25], PT fronteira organizational 'organizational boundary' [IAASB: 28].

- Compound monomials, which are set term clusters that comprise three and more terms in the monomial structure and are characterized by a higher degree of variability in modifying terms. For example, some of such monomials are as follows: PT informação financeira historica 'historical financial information' [IAASB: 30], PT informação financeira não ajustada 'unadjusted financial information' [IAASB: 30].

- Complex monomials, which at first sight 
may look similar to compound monomials as the number of terms in the structure exceeds three terms. However, such complex monomials feature a more complex nature, for their subordinated expression at the grammatical and syntactical levels: PT pessoa externa adequadamente qualificada 'adequately qualified external person' [IAASB: 36]. One of the brightest examples can be a two-tier English monomial EN those charged with governance that corresponds to a simplified PT encarregados da governação (literally) 'charged with governance' [IAASB: 25], the latter missing that two-tier complex nature.

Classification $B$ regards monomials in Portuguese for $A \& A$ in strict adherence to the morphological class of the head term in the monomial structure. Thus, the enlisted groups are the most frequently used to trace the trend in the monomial coinage and usage in Portuguese for A\&A:

- Nounal: PT equipa de trabalho 'personnel' [IAASB: 26], PT governação da entidade 'management of the entity' [IAASB: 28],

- Verbal: PT olhar para um processo ou procedimento 'to look at a process or procedure' [IAASB: 25], PT [um processo] para apreciar a eficácia 'a process to assess the effectiveness' [IAASB: 32],

- Adjectival: PT relevante(s) para o relato financeiro 'relevant to financial reporting' [IAASB: 33],

- Adverbial: PT adequadamente qualificado(a) 'adequately qualified' [IAASB: 36].

Classification $C$ rests on the "syntagmatic relations within the bound terms, [which] are immediate linear relations between [...] terminological units in a segmental sequence" in Chaika (2015), inasmuch such linear relations between the terms in the monomial unveil specific logical, grammatical, and semantic arrangement in the concept and designation [4]. The below groups view monomials in Portuguese for $A \& A$ via the lens of syntagmatic relations:

- Predicative: PT prestar serviços to provide services' [IAASB: 33], e.g. PT Uma organiza ção terceira (ou um segmento de uma organização terceira) que presta serviços a entidades utentes que são parte dos sistémas de informação dessas entidades relevantes para o relato financeiro - EN $A$

\section{References}

1. Alber-Dewolf, R. (1980) "Compte rendu de Hoffman L., Languages for Special Purposes as a Means of Communication: An Introducntion", p. 31 .

2. Aronoff, M., Rees-Miller, J. (2017). The Handbook of Linguistics. Hoboken, NJ: John Wiley \& Sons.

3. Cabré, M. T. (2002). Terminología y lingüística: la teoría de las puertas abiertas. Estudios de Lingüística del Español (ELiEs). Red Iris (España: third-party organization (or segment of a third-party organization) that provides services to user entities that are part of those entities' information systems relevant to financial reporting,

- Objective: PT prestar serviços [a entidades utentes] to provide services [to user entities]' [IAASB: 33],

- Attributive: PT levado a concluir 'leading to conclude' [IAASB: 29], PT [um processo] para apreciar a eficácia 'a process to assess the effectiveness' [IAASB: 32],

- Adverbial: PT devidamente admitido na lei 'duly anticipated by the law', PT adequadamente qualificado(a) 'adequately qualified' [IAASB: 36].

As demonstrated above, the study of the monomials in Portuguese for $A \& A$ can provide solid ground for different research areas. Monomials in Portuguese for A\&A as well as other domains of professional knowledge and in other languages are not only set terminological expressions and/or collocations of nounal nature, but also appeal with their variability for research foci.

Conclusion. The present study results in integration of the current findings and the previously found research data as to the monomial coinage, conceptual framework and functional use of monomials in the English, Ukrainian, and Portuguese languages. The revealed distinct similarities identified in the course of work may take to relevant classifications attributable with the same set of criteria for Slavic, Germanic, and Romance languages when performing jobs for comparative and contrastive analysis of the language material in respective LSP corpora. Variability in the monomial structure in Portuguese for $A \& A$ and approaches to the monomial analysis allows for some classifications adopted, i.e. according to the structural analysis, morphological class of the head term in the monomial structure, and a syntactical role in a sentence under a professional setting. Based on the findings, further it can be material to contrast the monomials in the English, Ukrainian, and Portuguese languages in a given terminology and identify the most frequently used monomial patterns in a professional context.

Universidad Autónoma de Barcelona).

4. Chaika, O. (2015). Identity in CrossLinguistic Legal Syntax. Proceedings of the MtS conference (University of Prešov).

5. Chaika, O. (2019). Binomials in English Audit Terminology. International Journal of Philology. Kyiv : «Mllenium». Vol. 10, no 3, pp. 68-73. DOI: http://dx.doi.org/10.31548/philolog2019.03.068

6. Chaika, O. (2020). Structure of Simplified Monomials in Ukrainian for Audit and Accounting. In: Scientific journal. «International Journal of 
Philology». Kyiv : «Milenium». Vol. 11. No. 4. P.108-112.

7. Chaika (Čajka), O. (2020). Structure of BiTerm Monomials in English for Audit and Accounting. In: Euromentor Journal. Volume XI, No. 4. P. 158174. URL: http://euromentor.ucdc.ro/EUROMENTOR december2020.pdf

8. Chaika, O. (2020). Monomials as Set Term Clusters in Terminologies. In: Scientific journal. «International Journal of Philology». Kyiv: «Milenium», Vol. 11. No. 3. P. 96 -99.

http://journals.nubip.edu.ua/index.php/Filol/article/ view/14649

9. Chaika, O. (2021). Nounal Simplified Monomials in Ukrainian for Audit and Accounting. In: International Journal of Social Science and Human Research, Vol. 4 (2). ISSN (print): 26440679, ISSN (online): 2644-0695. P. 578-583.

10. Darchuk, N. (2019). Compiling of the Electronic Dictionary of Models of the Ukrainian Language Multicomponent Complex Sentences. Ukrajinske Movoznavstvo (Ukrainian Languistics), no 1 (49), p. 117-129. https//doi.org/ 10.17721/um/49(2019).117-129.

11. L'Homme, M.-C. (2015). Terminologies and Taxonomies. In: The Oxford Handbook of the Word / Ed. by John R Taylor. DOI: 10.1093/oxfordhb/9780199641604.013.008.

12. Khan, S. A. (2016) The Distinction between Term and Word: A Translator and Interpreter Problem and the Role of Teaching Terminology. Procedia: Social and Behavioral
Sciences. International Conference on Teaching and Learning English as an Additional Language, GlobELT 2016, 14-17 April 2016, Antalya, Turkey.

13. Luchyk, A. (2016). Dynamika movnoyi normy i problemy kodyfikatsiyi [Dynamics of language norm and codification problem]. Magisterium (mov), 62 (12), 51-55.

14. Pearson, J. (1998). Term in Context. John Benjamin Publishing.

15. Rondeau, G. (1984). Introduction à la terminologie (Introduction to terminology). Quebec, CA: Gaetan Morin Editeur 2nd ed. 1984. 238 p., ISBN 2-89105-137-8.

16. Sager, J. (1990). A Practical Course in Terminology Processing. Amsterdam/Philadelphia: John Benjamins, 1990. xi + 254pp. ISBN 90272 20778(pb).

17. Shynkaruk, V. (2002). Katehoriyi modusu i dyktumu u strukturi rechennya: Monohrafiya [Categories of mode and dictum in the sentence structure]. Chernivtsi: Ruta.

18. Soare, R. I. (2011). Computability Theory and Applications: The Art of Classical Computability.

19. Sonneveld, H, Loenning, K. (1994). Introducing terminology. Terminology, p. 1-6.

20. Wüster, E. (1979). Einführung in die allgemeine Terminologielehre und terminologische Lexikographie. Teil 1-2. Springer-Verlag.

21. International Audit and Assurance Standards, Volume I published by the IAASB International Audit and Assurance Standards Board. = IAASB as referred to in the publication.

\section{ВАРІАТИВНІСТЬ СТРУКТУРИ МОНОМІВ В ПОРТУГАЛЬСЬКІЙ МОВІ ДЛЯ ОБЛІКУ Й АУДИТУ}

\section{О. І. Чайка}

Анотація. У статті розглядається португальська мова у сфрері провадження діяльності 3 аудиту та бухгалтерського обліку як особлива область знань, що вивчає з-поміж іншого процеси творення, вжитку й фрункціонування термінологічних виразів або термінологічних колокацій, за класифрікацією термінів Л. Черноватого, або, відповідно до класифікації Чайки (2019, 2020), мовних і мовленнєвих мономів як сукупності усталених синтаксичних конструкцій термінологічної природи у відповідних фрахових мовах (термінологіях, або мовах спеціального призначення). Для того, щоб продемонструвати варіативність застосування методології для аналізу мовних мономів, цього разу португальська мова зі сфрери аудиту та бухгалтерського обліку слугуватиме джерельною базою для досягнення визначених иілей. Статmя має на меті розкрити певні підходи до аналізу структури монома в лінгвістиці. Такі підходи як відрізняються між собою, так і доповнюють один одного: від структурного аналізу сталих термінологічних кластерів (мономів) за кількістю компонентів / елементів у структурі монома, морфологічного класу стрижневого терміна (компонента) у мономній структурі до визначення їх ролі у реченні в рамках профресійного контексту, а також аналізу синтаксичних моделей як базових одиниць синтаксису, терміни (елементи) яких зв'язані між собою логічно, граматично та за змістом. У статті виявлено, що окремі подібності, ідентифіковані в ході аналізу мовних і мовленнєвих мономів португальської мови у сорері аудиту та бухгалтерського обліку, можуть застосовуватися як певні критерії для створення класифікацій, що характеризують процеси й особливості творення термінологічних сполучень усталеного вжитку в сорері бухгалтерського обліку й аудиту в українській, англійській, німецькій, іспанській мов у слов'янській, германській та романській мовних сім'ях. Перспективні напрямки дослідження полягають у проведенні порівняльного та зіставно-типологічного аналізу мовного й мовленнєвого матеріалу у відповідних корпусах фрахової мови з обліку та аудиту.

Ключові слова: моном (мономіал), фрахова мова, термінологія, португальська мова для обліку $\breve{u}$ aydumy. 